Note

\title{
Failure to Detect Brown Adipose Tissue Uncoupling Protein mRNA in Benign Symmetric Lipomatosis (Madelung's Disease)
}

\author{
Tsutomu KAZUMI, Daniel RICQUIER*, Tetsuo MAEDA, \\ TADAYUKI MASUDA, ToShiki HOZUMI, Yoshihiko ISHIDA, \\ AND MUNEYOSHI YOSHIDA \\ Division of Endocrinology and Metabolism, Department of \\ Medicine, Hyogo Medical Center for Adults, Akashi 673, Japan, \\ and *Centre de Recherche sur L'endocrinologie Moleculaire et le \\ Developpment, Centre National de la Recherche Scientifique, France
}

\begin{abstract}
We report a case of benign symmetric lipomatosis with hypothyroidism. Functional abnormalities and distribution of lipomas in benign symmetric lipomatosis suggest that the lipomas in this disorder may represent brown adipose tissue. In conditions where mRNAs of uncoupling protein, which is believed to be unique for brown adipose tissue mitochondria, were detected in one $\mu \mathrm{g}$ of poly $\left(\mathrm{A}^{+}\right)$rat brown fat RNA, no signal at all was found in the lipomatous tissue, suggesting that the masses of benign symmetric lipomatosis are not functional brown adipose tissue.
\end{abstract}

Key words: Uncoupling protein, Benign symmetric lipomatosis.

(Endocrine Journal 41: 315-318, 1994)

BENIGN SYMMETRIC lipomatosis (Madelung's disease) $[1,2]$ is a disease characterized by the localized symmetrical accumulation of an excessive amount of adipose tissue. It has been suggested that lipomatous masses form as a result of triglyceride accumulation in embryonal residues of brown adipose tissue [3-6]. We have tested this suggestion by measuring the mRNA level of uncoupling protein (UCP), which is believed to be unique for brown adipose tissue mitochondria, directly in lipomatous tissue taken from a patient with benign symmetric lipomatosis and hypothyroidism.

Received: September 13, 1993

Accepted: January 21, 1994

Correspondence to: Dr. Tsutomu KAZUMI, Division of Endocrinology and Metabolism, Department of Medicine, Hyogo Medical Center for Adults, 13-70 Kita-ohji-cho, Akashi 673, Japan

\section{Patient and Methods}

The patient under study was a 73-year-old male who, since the age of 60 , had begun to develop symmetrical fat accumulation in the neck, nape, back and upper trunk. Elsewhere, however, there was no excess subcutaneous fat and he never noted loss of fat in the uninvolved areas.

Since the age of 18 , he had consumed about 150 $\mathrm{g}$ of an alcoholic beverage (as Japanese "sake") every day until he was 60 years old, when jaundice resulted in admission to another hospital where a diagnosis of alcoholic hepatitis was made.

Physical examinations revealed no abnormalities except lipomatosis (Fig. 1). Abnormal laboratory values included uric acid, $10.4 \mathrm{mg} / \mathrm{dl} ; \mathrm{TSH}, 256.0$ $\mu \mathrm{IU} / \mathrm{ml} ; \mathrm{T}_{3}$, less than $0.5 \mathrm{ng} / \mathrm{ml}$ and $\mathrm{T}_{4}, 0.9 \mu \mathrm{g} / \mathrm{d} l$. However, his thyroid glands were not palpable.

A sample of lipomatous tissue ( $3 \mathrm{~g}$ ) and one of non-lipomatous tissue $(4 \mathrm{~g})$ were obtained from lesions located at the right shoulder under local an- 


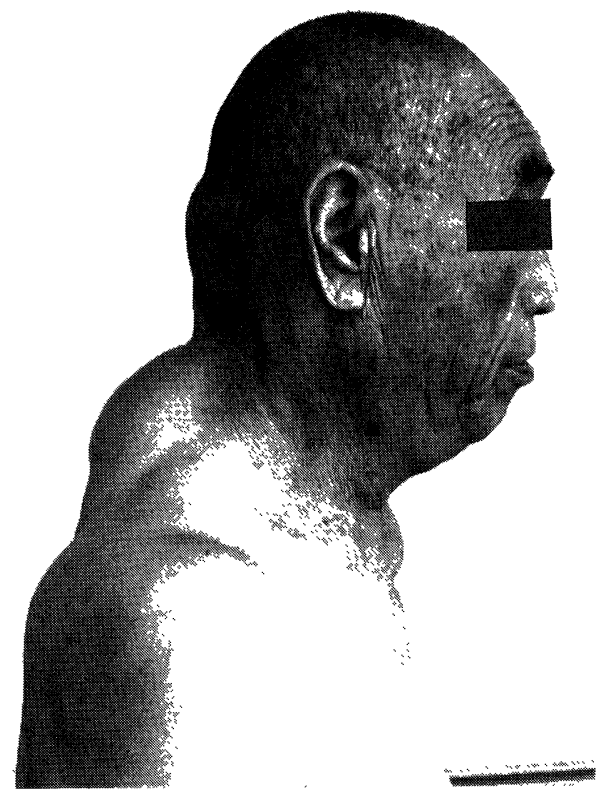

Fig. 1. Lateral view of patient with benign symmetric lipomatosis.

esthetic, but from a site well removed from the local anesthetic administration. A small portion of each sample was subjected to light microscopic examinations and the rest was immediately placed on a block of dry ice and kept frozen at $-20^{\circ} \mathrm{C}$ until transferred to Centre de Recherche sur L'endocrinologie Moleculaire et le Developpment, Meudon, France, where brown adipose tissue UCP mRNAs were measured as previously reported [8, 9]. Briefly, total RNA was extracted by the phenol method. Poly $\left(\mathrm{A}^{+}\right)$RNA was isolated by chromatography on oligothymidilic acid-cellulose [10]. RNAs were separated in $1.5 \%(\mathrm{~W} / \mathrm{V})$ agarose gel containing folmaldehyde and transferred to a nylon membrane. Hybridization of ${ }^{32} \mathrm{P}$-labelled probes to RNAs was carried out as described previously [11]. With the same probe, H-UCP-0.5, which was also used in this study, UCP mRNA was detected in brown adipose tissue of human adults [8].

\section{Results and Discussion}

Light microscopic examinations confirmed pre- vious findings [12] showing that specimens resembled normal adult adipose tissue with no evidence of active fat or connective tissue proliferation. There was no evidence of brown fat (Fig. 2).

In conditions where rat UCP mRNAs were detected in one $\mu \mathrm{g}$ of poly $\left(\mathrm{A}^{+}\right)$rat brown fat RNA, no signal at all was found in the lipomatous tissue or in the subcutaneous white adipose tissue taken from the patient (Fig. 3).

Kodish et al. [6] examined the in vivo metabolism of free fatty acids in a patient with benign symmetric lipomatosis. They observed the inability of the patient's adipose tissue to release free fatty acids in response to physiologic stimuli and abnormalities in the response of free fatty acids to insulin and epinephrine, both of which are consistent with functional sympathetic denervation of adipose tissue. The same conclusion was reached by Enzi et al. [4] and Desai et al. [5]. Since the lipomatous fat in benign symmetric lipomatosis is similar in dis-

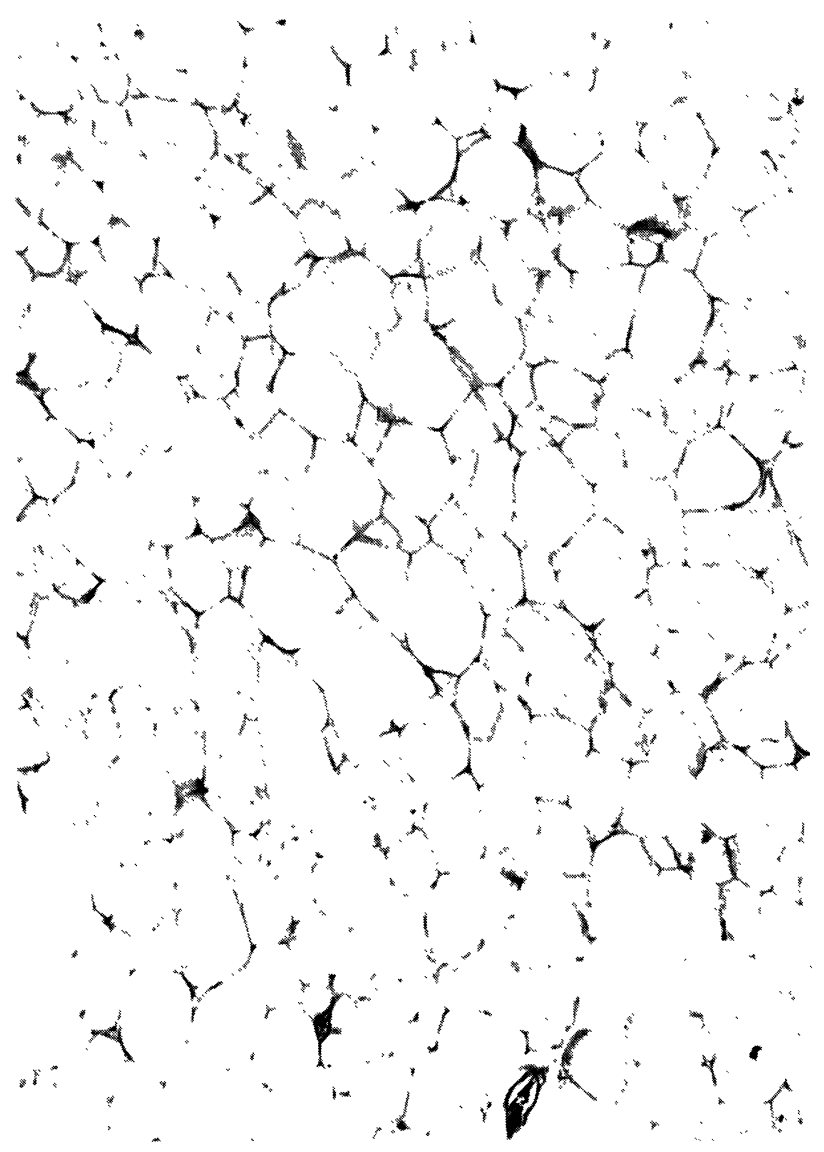

Fig. 2. Lipoma with normal adult adipose tissue with no evidence of brown fat. 

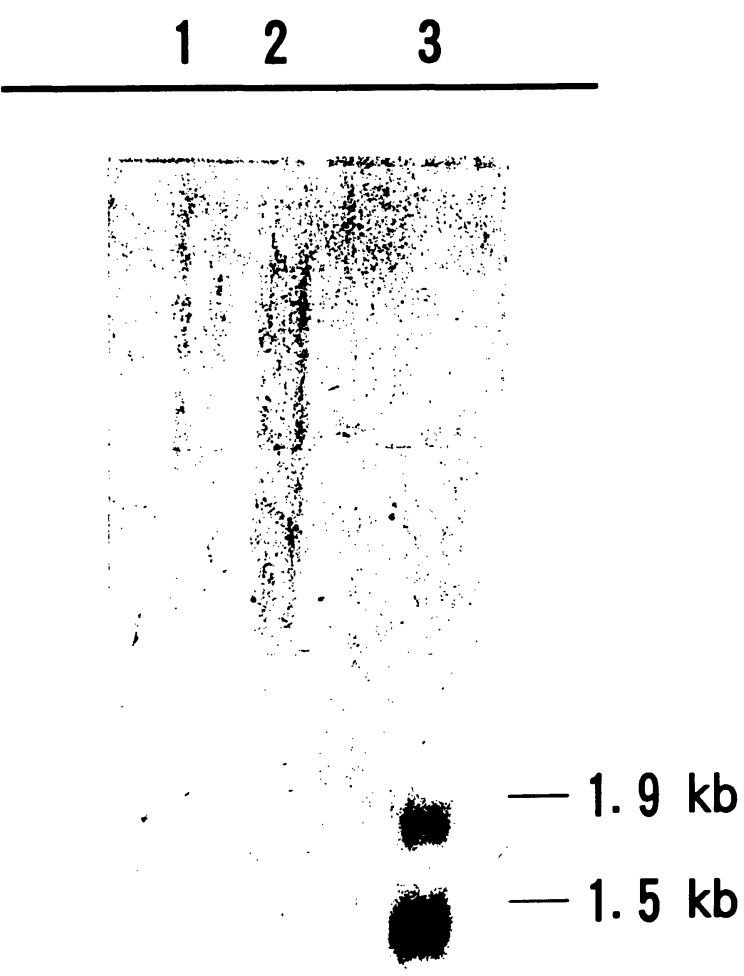

Fig. 3. Northern analysis of human brown adipose tissue uncoupling protein mRNA in benign symmetric lipomatosis. Lane $1: 1.2 \mu \mathrm{g}$ of poly $\left(\mathrm{A}^{+}\right) \mathrm{RNA}$ from subcutaneous white adipose tissue of the patient. Lane 2: $3.4 \mu \mathrm{g}$ of poly $\left(\mathrm{A}^{+}\right)$RNA from a lipoma of benign symmetric lipomatosis. Lane 3: $1.0 \mu \mathrm{g}$ of rat brown adipose tissue poly $\left(\mathrm{A}^{+}\right)$RNA. tribution to the brown fat of human newborns and rodents which may hypertrophy after denervation, they suggested that the lipomas in this disorder may represent such brown adipose tissue.

In the present study, however, brown adipose tissue UCP mRNA was not detected in benign symmetric lipomatosis, suggesting that the amount of UCP mRNA in this adipose depot was very small, below the limit of detectability of the assay. This would not necessarily invalidate the hypothesis that the lipoma has a brown adipose tissue origin. There are several explanations for failure to detect brown adipose tissue UCP mRNA in benign symmetric lipomatosis. First, if, as suggested by many authors [4-6], the disorder is associated with "functional sympathetic denervation" of adipose tissue, one would expect the disappearance of UCP mRNA as it is under sympathetic control [13]. Secondly, it is reasonable to assume that the lipomas are brown fat cells which fail to reach late differentiation stages, as UCP is a late marker of differentiation [9]. Another possible explanation is that fat cells in the lipomas may originate in mature brown adipocytes by de-differentiation. In this case, the lipomas contain little or no UCP mRNA, especially if the dedifferentiation process is completed (the patient was 73 years old and had had the lipoma for at least 13 years). In any event, failure to detect UCP mRNA in benign symmetric lipomatosis suggests that the majority of the cells present in the lipoma studied are not typical functioning brown adipocytes.

\section{References}

1. Launois PE, Bensaude $R$ (1989) De l'adenolipomatose symetrique. Bull Mem Soc Med Hop Paris 1: 298-318.

2. Launois PE, Bensaude R (1901) L'adenolipomatose symetrique a predominance cervicale chez la femme. Bull Mem Soc Med Hop Paris 18: 675-682.

3. Greene ML, Glueck CJ, Fujimoto WY, Seegmiller JE (1970) Benign symmetric lipomatosis (LaunoisBensaude adenolipomatosis) with gout and hyperlipoproteinemia. Am J Med 48: 239-246.

4. Enzi G, Inelmen EM, Baritussio A, Dorigo P, Prosdocimi M, Mazzoleni F (1977) Multiple symmetric lipomatosis. A defect in adrenergic-stimulated lipolysis. J Clin Invest 60: 1221-1229.

5. Desai KS, Zinman B, Steiner G (1979) Multiple symmetric lipomatosis (Launois-Bensaude syn- drome)-adipose tissue insensitivity to cyclic AMP. J Clin Endocrinol Metab 49: 307-309.

6. Kodish ME, Alsever RN, Block MB (1974) Benign symmetric lipomatosis: functional sympathetic denervation of adipose tissue and possible hypertrophy of brown fat. Metabolism 23: 937-945.

7. Nicholls DG, Locke R (1984) Thermogenic mechanism in brown fat. Physiol Rev 64: 1-64.

8. Bouillaud F, Villarroya F, Hentz E, Raimbault $S$, Cassard A, Ricquier D (1988) Detection of brown adipose tissue uncoupling protein mRNA in adult patients by a human genomic probe. Clin Sci 75 : 21-27.

9. Casteilla L, Champigny O, Bouillaud F, Robelin J, Ricquier D (1989) Sequential changes in the expression of mitochondrial protein mRNA during the 
development of brown adipose tissue in bovine and ovine species. Biochem J 257: 665-671.

10. Aviv H, Leder P (1972) Purification of biologically active globin messenger RNA by chromatography on oligothymidilic acid-cellulose. Proc Natl Acad Sci USA 69: 1408-1412.

11. Bouillaud F, Ricquier D, Thibault J, Weisenbach J (1985) Molecular approach to thermogenesis in brown adipose tissue: cDNA cloning of the mito- chondrial uncoupling protein. Proc Natl Acad Sci USA 82: 445-448.

12. Argenta LC, McClatchey KD, Ferrell WJ, Newman $\mathrm{MH}$ (1981) Benign symmetrical lipomatosis. Head and Neck Surg 3: 240-243.

13. Forest C, Doglio A, Casteilla L, Ricquier D, Ailhaud G (1987) Expression of the mitochondrial uncoupling protein in brown adipocytes. Expt Cell Res 168: 233-246. 